\title{
МАТЕМАТИЧНА МОДЕЛЬ ПРОЦЕСУ РОЗРЯДЖЕННЯ ЄМКІСНОГО НАКОПИЧУВАЧА В АВТОНОМНІЙ ВІТРОЕЛЕКТРОУСТАНОВЦІ 3 ЕЛЕКТРОДИНАМІЧНИМ ПРИВОДОМ НАСОСУ
}

\author{
В.М. Головко, проф., докт. техн. наук, В.П. Кохансвич, канд.техн.наук, М.О. Шихайлов, \\ А.М. Донець, канд.техн.наук, І.Ю. Перькова, інженер \\ Інститут відновлюваної енергетики НАН України, 02094, м. Київ, вул. Гната Хоткевича, 20А
}

Нерівномірність та випадковість надходження енергї від відновлюваних джерел енергї спонукає до розробки електроімпульсних установок для ї̈ використання. Одною з причин, що стримують використання таких установок $\epsilon$ відсутність відповідних математичних моделей, щуо не дає можливості здійснити оцінку зусиль, які виникають при роботі виконавчих елементів. У відомих електродинамічних приводах величина імпульсу сили зазвичай визначається як величина, пропориійна діаметру котушки і рівного їй за діаметром електропровідного диску. Однак експериментально встановлено, що існує максимальна величина діаметрів конструктивних елементів електродинамічного приводу, при перевищенні якої помітно знижується його ефективність. Також на ефективність електродинамічного приводу впливає товщина електричної котушки, оскільки ККД прочесу передачі електричної енергї від конденсатора в електропровідний диск електродинамічного приводу падає при великій товщині котушки. Крім того, без розуміння прочесу розрядження в електроімпульсних установках часто неможливо здійснити вибір параметрів зарядних пристроїв та ємнісних накопичувачів. Бажано здійснювати таке узгодження щуоб зарядження і розрядження були взаємонезалежними, щьо покладається на систему керування роботою імпульсного пристрою. Найчастіше схема керування вимикає розрядний блок від зарядного під час прочесу розрядження.

Розроблена математична модель прочесу розрядження ємнісного накопичувача на робочий орган електродинамічного привода насосу,що дозволила визначити вплив його параметрів на тривалість імпульсу розрядження . Для розрахунку індуктивності котушки виконавчого елементу привода запропоновано вираз, обчислення за яким дає задовільний результат. Розрахункові дані збігаються з результатами експериментальної стендової перевірки. Бібл. 7, рис. 2.

Ключові слова: автономна вітроелектроустановка, ємнісний накопичувач, електроімпульсна установка, електродинамічний привод, розрядження ємкісного накопичувача.

\section{MATHEMATICAL MODEL OF THE EMC DISCHARGE PROCESS SOLUTION IN ALONE STATE WIND TURBINE WITH ELECTRODYNAMIC PUMP DRIVER}

\author{
V. Golovko, professor., doctor of technical science, V. Kohanevich, candidate of technical science, M. Shikhailov, A. Donets, can-
} didate of technical science, I. Perkova, engineer

Renewable Energy Institute of NAS of Ukraine, 02094, Kyiv, vul. Hnat Khotkevich, 20A

The unevenness and incidentality of energy from renewable energy sources prompts the development of electropulse units for its use. One of the reasons behind the constraint of the use of such installations is the lack of appropriate mathematical models, which makes it impossible to evaluate the efforts that arise when operating the operating elements. In known electrodynamic drives, the magnitude of the power pulse is usually defined as a value proportional to the diameter of the coil and equal to the diameter of the conductive disk. However, it has been experimentally established that there is a maximum value of the diameters of the structural elements of the electrodynamic drive, the excess of which significantly decreases its efficiency. Also, the efficiency of the electrodynamic drive is influenced by the thickness of the electric coil, since the efficiency of the process of transferring electric energy from the condenser to the electrodynamic drive of the electrodynamic drive falls at a large thickness of the coil. In addition, without understanding the discharge process in electropulse units, it is often not possible to select the parameters of chargers and capacitive drives. It is desirable to make such an agreement that charging and discharging are interdependent, which relies on the control system of the impulse device. Often the control circuitry turns off the discharge unit from the charger during the discharge process.

The mathematical model of the process of discharging a capacitive drive to the working body of the electrodynamic drive of the pump was developed, which allowed to determine the influence of its parameters on the duration of the discharge pulse. To calculate the inductance of the coil of the actuator, an expression is proposed, the calculation of which gives a satisfactory result. Estimated data coincides with the results of the experimental bench check. Ref. 7, fig. 2.

Keywords: autonomous wind power installation, capacitive drive, electric-pulse unit, electrodynamic drive, discharge capacitance drive. 


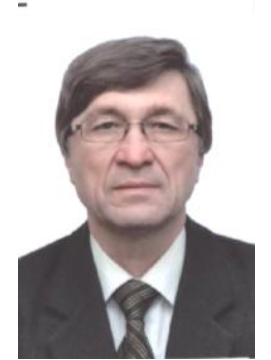

В.М. Головко

V. Holovko

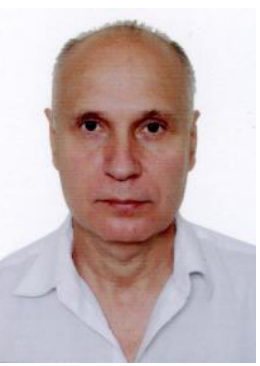

В.П. Коханєвич

V. Kokhanievych
Відомості про автора: провідний науковий співробітник Інституту відновлюваної енергетики НАН України.

Освіта: закінчив 1977 р. Українську сільськогосподарську академію за спеціальністю «Електрифікація сільського господарства».

Наукова сфера: відновлю-вані джерела енергії, вітроенергетика, вітроустановки малої потужності, автономні системи енергозабезпечення.

Публікації: 157

ORCID: 0000-0003-0195-9654

Контакти: тел./факс +38-044-206-28-09

e-mail: renewable@ukr.net

Відомості про автора: старший науковий співробітник Інституту відновлюваної енергетики НАН України.

Освіта: закінчив 1979 р. Київський політехнічний інститут за спеціальністю «Технологія машинобудування, метало ріжучі верстати та інструменти».

Наукова сфера: вітроенергетика, вітроустановки малої потужності, системи регулювання та захисту.

Публікації: 129.

ORCID: 0000-0003-0033-1355

Контакти: тел./факс +38-044-206-28-09

e-mail: renewable@ukr.net

Відомості про автора: науковий співробітник Інституту відновлюваної енергетики НАН України.

Освіта: закінчив 1979 р. Київський політехнічний інститут за спеціальністю «Гідропневмоавтоматика та гидропривод».

Наукова сфера: вітроенергетика, вітроустановки малої потужності, системи управління.

Публікації: 203

ORCID: 0000-0003-1845-9904

Контакти: тел./факс +38-044-206-28-09

e-mail: renewable@ukr.net

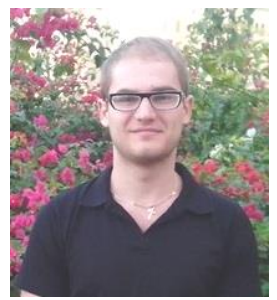

A.М. Донеиь

A. Donets
Відомості про автора: науковий співробітник Інституту відновлюваної енергетики НАН України.

Освіта: магістр енергетики НТУУ «КПІ ім. I. Сікорського», факультет електроенерготехніки та автоматики, спеціальність: «відновлювані джерела енергії»

Наукова сфера: енергетичні системи, перетворення видів енергії, автоматизація і моделювання процесів.

Публікації: 10.

ORCID: 0000-0003-4486-5666

Контакти: тел./факс +38-044-206-28-09

e-mail: renewable@ukr.net
Author information: chief researcher at Institute for Renewable Energy, National Academy of Sciences of Ukraine.

Education: graduated from the Ukrainian Agricultural Academy in 1977 with the degree of "Electrification of Agriculture".

Research area: renewable sources of energy, wind power systems, small capacity wind units, autonomous power systems.

Publications: 157.

ORCID: 0000-0003-0195-9654

Contacts: тел./факс +38-044-206-28-09

e-mail: renewable@ukr.net

Author information: senior researcher at Institute for Renewable Energy, National Academy of Sciences of Ukraine.

Education: graduated from the Kyiv Polytechnic Institute in 1979 with the specialization "Technology of Machine-Building, Metal Cutting Machines and Tools".

Research area: power systems, converting types of energy, automation and modeling processes. wind power systems, small capacity wind units, control systems and protect.

Publications: 129.

ORCID: 0000-0003-0033-1355

Contacts: тел./факс +38-044-206-28-09

e-mail: renewable@ukr.net

Author information: researcher in at Institute for Renewable Energy, National Academy of Sciences of Ukraine.

Education: graduated from the Kyiv Polytechnic Institute in 1979 with the specialty "Hydropneumatic and Hydraulic Drive";

Research area: wind power systems, small capacity wind units, control systems.

Publications: 203

ORCID: 0000-0003-1845-9904

Contacts: тел./факс +38-044-206-28-09

e-mail: renewable@ukr.net

Author information: Researcher at Institute for Renewable Energy, National Academy of Sciences of Ukraine.

Education: Master of Science, National Technical University of Ukraine "Kyiv Polytechnic Institute", Faculty of Electric Power Engineering and Automation, Department of Renewable Sources of Energy.

Research area: power systems, converting types of energy, automation and modeling processes.

Publications: 10

ORCID: 0000-0003-4486-5666

Contacts: тел./факс +38-044-206-28-09

e-mail: renewable@ukr.net 


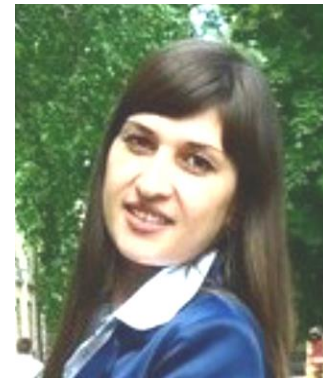

Відомості про автора: інженер Інституту відновлюваної енергетики НАН України.

Освіта: магістр енергетики НТУУ «КПІ ім.І.Сікорського», факультет електроенерготехніки та автоматики, спеціальність: «відновлювані джерела енергії»

Наукова сфера: вітроенергетика, вітроустановки малої потужності, системи управління.

Публікації: 6.

ORCID: 0000-0002-9070-1593

I. Percova

Контакти: тел./факс +38-044-206-28-09

e-mail: renewable@ukr.net
Author information: Engineer to the Institute of Innovative Energy Energetics of the National Academy of Sciences of Ukraine.

Education: Master of Science, National Technical University of Ukraine "Kyiv Polytechnic Institute", Faculty of Electric Power Engineering and Automation, Department of Renewable Sources of Energy.

Research area: vietroenergetic, virtual installation is not enough, system management.

Publications: 6.

ORCID: 0000-0002-9070-1593

Contacts: тел./факс +38-044-206-28-09

e-mail: renewable@ukr.net
Перелік використаних позначень та скорочень:

$L_{l} \quad$ - індуктивності котушки (першого контуру);

$L_{2} \quad$ - індуктивність диску (другого контуру);

$M \quad$ - взаємоіндуктивність між котушкою та диском;

$U_{C} \quad$ - напруга на конденсаторі;

$R_{l} \quad$ - опір котушки;

$R_{2} \quad$ - опір диску;

Вступ. Розробка електроімпульсних установок для реалізації енергії, що отримується від відновлюваних джерел енергії, є одним із шляхів їх широкого впровадження. Проте нерівномір-ність та випадковість ії надходження вимагає застосування різноманітних накопичувачів: хімічних, індуктивних, ємнісних, механічних та ін. Кожний із них має свою область застосування. Для створення коротких імпульсів доцільно використовувати ємнісні накопичувачі, так як час видачі енергії 3 них складає $10^{-3} \ldots 10^{-6} \mathrm{c}[1,2]$.

Одною 3 причин, що стримують використання електроімпульсних установок $є$ відсутність відповідних математичних моделей, що не дає можливості здійснити оцінку зусиль, які виникають при роботі виконавчих елементів. У відомих електродинамічних приводах величина імпульсу сили зазвичай визначається як величина, пропорційна діаметру котушки і рівного їй за діаметром електропровідного диску. Однак експериментально встановлено, що існує максимальна величина діаметрів конструктивних елементів електродинамічного приводу, при перевищенні якої помітно знижується його ефективність. Також на ефективність електродинамічного приводу впливає товщина електричної котушки, оскільки ККД
$R_{K} \quad-$ опір ключа;

$C \quad$ - ємність конденсатора;

$i_{1} \quad-$ струм в котушці;

$i_{2}$ - струм в диску;

но - абсолютна магнітна проникненість; процесу передачі електричної енергії від конденсатора в електропровідний диск електродинамічного приводу падає при великій товщині котушки. $[3,4]$ Крім того, без розуміння процесу розрядження в електроімпульсних установках часто неможливо здійснити вибір параметрів зарядних пристроїв та ємнісних накопичувачів. Бажано здійснювати таке узгодження щоб зарядження i розрядження були взаємонезалежними, що покладається на систему керування роботою імпульсного пристрою. Найчастіше схема керування вимикає розрядний блок від зарядного під час процесу розрядження.

Постановка задачі. Розробити математичну модель процесу розрядження ємнісного накопичувача на робочий орган електродинамічного привода насосу.

Методи дослідження. Для дослідження режиму розрядження ємкісного накопичувача на робочий орган електродинамічного привода насосу, у складі автономної вітроелектричної установки проводились шляхом моделювання за допомогою програмного пакету Mathcad.

Результати дослідження. Заступна схема для дослідження процесу розрядження ємкісного накопичувача на електродинамічний привід насосу наведена на рис. 1 . 


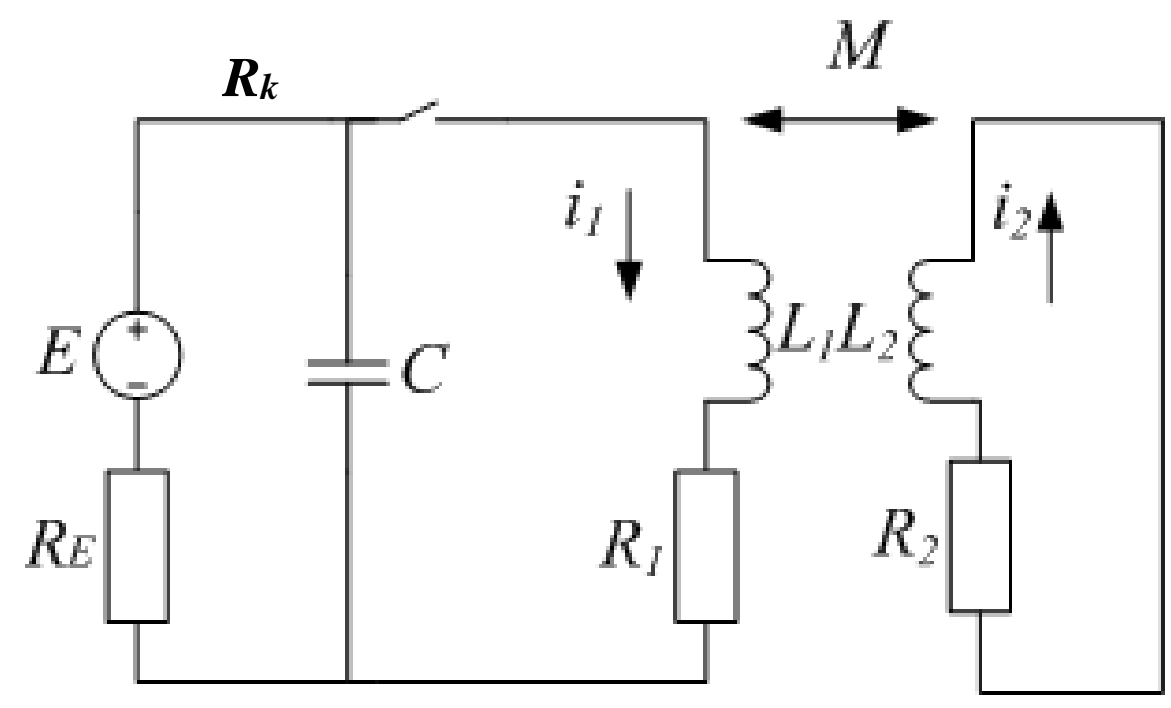

Рис. 1. Заступна схема розрядження ємкісного накопичувача на електродинамічний привід насосу.

Fig. 1. The following diagram of the discharging of the capacitive drive on the electrodynamic pump drive.

Вихідна система диференціальних рівнянь має вигляд:

$$
\left\{\begin{array}{l}
L_{1} \frac{d i_{1}}{d t}-M \frac{d i_{2}}{d t}+i_{1}\left(R_{1}+R_{k}\right)-U_{c}=0 \\
C \frac{d U_{c}}{d t}=-i_{1} \\
L_{2} \frac{d i_{2}}{d t}-M \frac{d i_{1}}{d t}+i_{2} R_{2}=0 .
\end{array}\right.
$$

Перепишемо систему (1) у наступному вигляді:

$$
\left\{\begin{array}{l}
\frac{d i_{1}}{d t}=\frac{M}{L_{1}} \frac{d i_{2}}{d t}-\frac{R_{1}+R_{k}}{L_{1}} i_{1}+\frac{1}{L_{1}} U_{c} ; \\
\frac{d U_{c}}{d t}=-\frac{1}{C} i_{1} ; \\
\frac{d i_{2}}{d t}=\frac{M}{L_{2}} \frac{d i_{1}}{d t}-\frac{R_{2}}{L_{2}} i_{2} .
\end{array}\right.
$$

Підставимо перше рівняння в (2) у останнє рівняння, а вираз для останнього рівняння - в вигляді:

$$
\begin{gathered}
\dot{\mathbf{x}}(t)=\mathbf{A} \cdot \mathbf{x}(t), \\
\text { де } \mathbf{x}(t)=\left(i_{1}(t), i_{2}(t), U_{c}(t)\right)^{\mathrm{T}}, . \mathbf{A}=\left[\begin{array}{ccc}
-\frac{L_{2}\left(R_{1}+R_{k}\right)}{L_{1} L_{2}-M^{2}} & -\frac{M R_{2}}{L_{1} L_{2}-M^{2}} & \frac{L_{2}}{L_{1} L_{2}-M^{2}} \\
-\frac{M\left(R_{1}+R_{k}\right)}{L_{1} L_{2}-M^{2}} & -\frac{R_{2} L_{1}}{L_{1} L_{2}-M^{2}} & \frac{M}{L_{1} L_{2}-M^{2}} \\
-\frac{1}{C} & 0 & 0
\end{array}\right] .
\end{gathered}
$$

перше. Результуюча система диференціальних рівнянь набуде вигляду:

$$
\left\{\begin{array}{l}
\frac{d i_{1}}{d t}=\frac{M^{2}}{L_{1} L_{2}} \frac{d i_{1}}{d t}-\frac{M R_{2}}{L_{1} L_{2}} i_{2}-\frac{R_{1}+R_{k}}{L_{1}} i_{1}+\frac{1}{L_{1}} U_{c} ; \\
\frac{d U_{c}}{d t}=-\frac{1}{C} i_{1} ; \\
\frac{d i_{2}}{d t}=\frac{M^{2}}{L_{1} L_{2}} \frac{d i_{2}}{d t}-\frac{M\left(R_{1}+R_{k}\right)}{L_{1} L_{2}} i_{1}+\frac{M}{L_{1} L_{2}} U_{c}-\frac{R_{2}}{L_{2}} i_{2} .
\end{array}\right.
$$

Приведемо до нормального вигляду та спростимо рівняння (3). В результаті отримаємо:

$$
\left\{\begin{array}{l}
\frac{d i_{1}}{d t}=-\frac{L_{2}\left(R_{1}+R_{k}\right)}{L_{1} L_{2}-M^{2}} i_{1}-\frac{M R_{2}}{L_{1} L_{2}-M^{2}} i_{2}+\frac{L_{2}}{L_{1} L_{2}-M^{2}} U_{c} \\
\frac{d i_{2}}{d t}=-\frac{M\left(R_{1}+R_{k}\right)}{L_{1} L_{2}-M^{2}} i_{1}-\frac{R_{2} L_{1}}{L_{1} L_{2}-M^{2}} i_{2}+\frac{M}{L_{1} L_{2}-M^{2}} U_{c} \\
\frac{d U_{c}}{d t}=-\frac{1}{C} i_{1} .
\end{array}\right.
$$

В векторній формі система (4) запишеться у 
Початкові умови наступні:

$$
\left(\begin{array}{l}
t_{0} \\
i_{1_{0}} \\
i_{2_{0}} \\
U_{c_{0}}
\end{array}\right)=\left(\begin{array}{l}
0 \\
0 \\
0 \\
100
\end{array}\right) .
$$

Система диференціальних рівнянь (4) записана в програмному пакеті Mathcad:

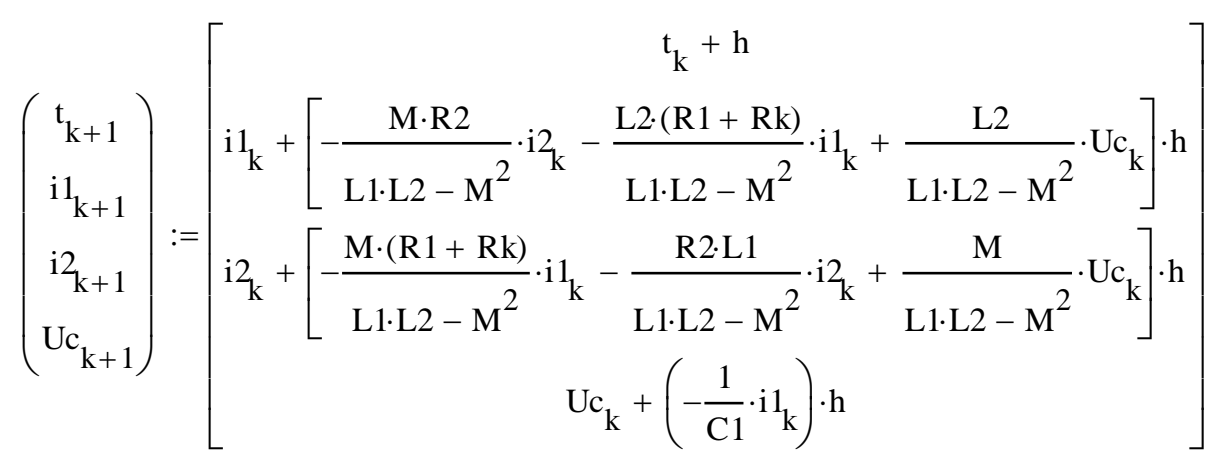

Для вирішення системи необхідно визначити значення індуктивності котушки $\left(\mathrm{L}_{1}\right)$, індуктивність приводного диску $\left(\mathrm{L}_{2}\right)$, взаємоіндуктивність між котушкою та приводним диском (M). Значення опорів котушки $\left(\mathrm{R}_{1}\right)$, диску $\left(\mathrm{R}_{2}\right)$ та ключа $\left(\mathrm{R}_{\mathrm{K}}\right)$, а також напруги зарядження ємнісного накопичувача та ємність конденсатора задаються згідно технологічних умов.

Котушка електродинамічного привода конструкційно виконана у вигляді плоскої колової спіралі, для розрахунку індуктивності якої запропоновано ряд виразів [5-7], обчислення за ними не дають задовільних результатів. Якщо скористатись залежністю для замкнутого колового кільця [6]:

$$
\begin{gathered}
L=N-G, \quad N=\mu_{0} R(\ln 8 R-2) ; \\
G=\frac{\mu_{0} l}{2 \pi} \ln q ;
\end{gathered}
$$

де $l$ - довжина витка; $q$ - середньоквадратична відстань площ поперечного перетину проводу самого від себе (q=R).

Тоді вираз для визначення індуктивності всієї котушки складе:

$$
L=\sum_{i=1}^{n} \mu_{0} R_{i}\left(\ln 8 R_{i}-2\right)-\sum_{i=1}^{n} \mu_{0} R_{i} \ln R_{i} .
$$

Індуктивність диска визначається за виразом [7] за $\alpha<\rho$ :

$$
\begin{gathered}
L=\mu_{0} R\left(\ln \frac{4}{\alpha-\rho}-0.5+\right. \\
+\frac{3 \alpha^{2}+\rho^{2}}{24} \ln \frac{4}{\sqrt{\alpha^{2}+\rho^{2}}}+f+\frac{\rho^{2}}{4} f_{2}, \\
\alpha=a / 2 R, \rho=r / 2 R ;
\end{gathered}
$$

де $a$ - товщина диску; $r$ - ширина кільця диску; $R$ - відстань від центру диску до його середини; $f, i$, $f_{2}$ - довідкові коефіцієнти [7].

Значення взаємоіндукції визначається за виразом [6]:

$$
M=\frac{\mu_{0}}{4 \pi} R F,
$$

де $R$ - радіус контурів; $F-$ довідковий коефіцієнт [15].

Результат вирішення системи (4) наведено на рис. 2. 


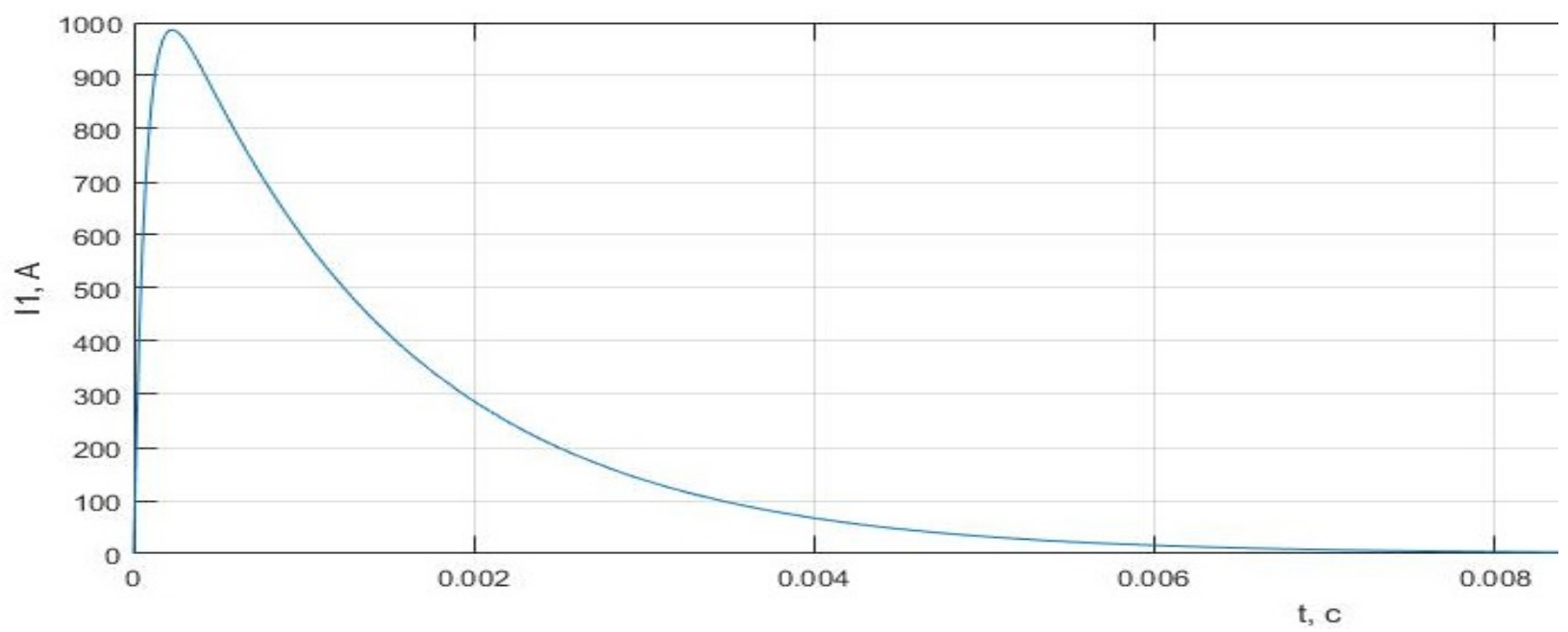

a)

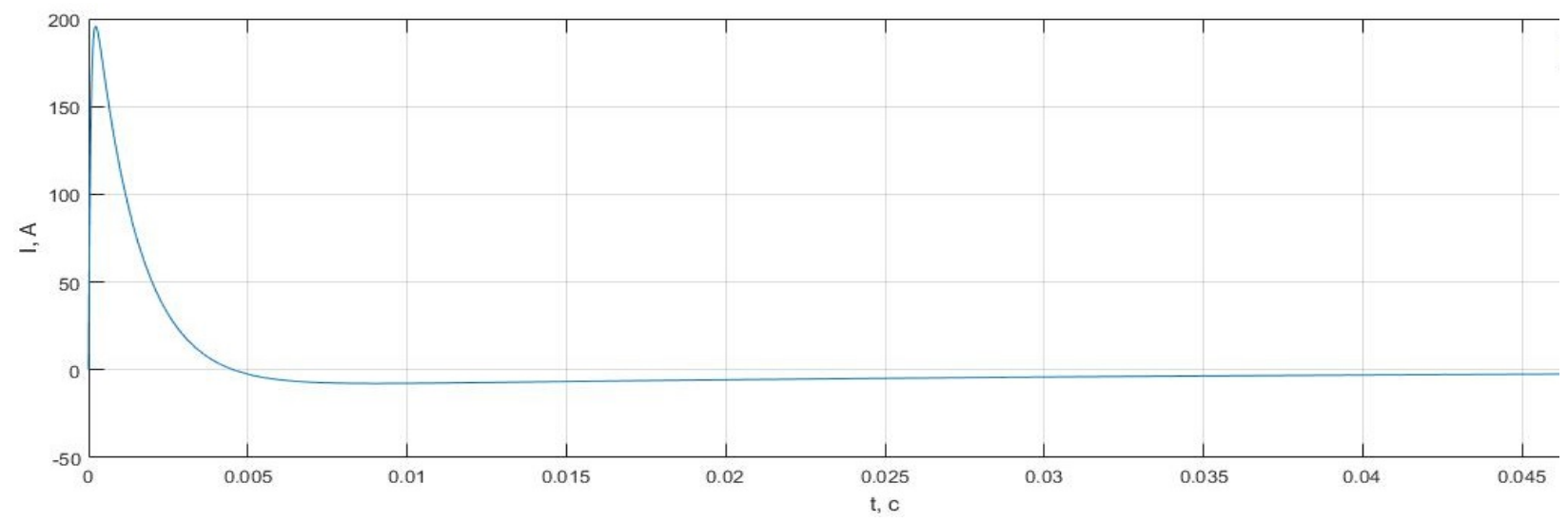

б)

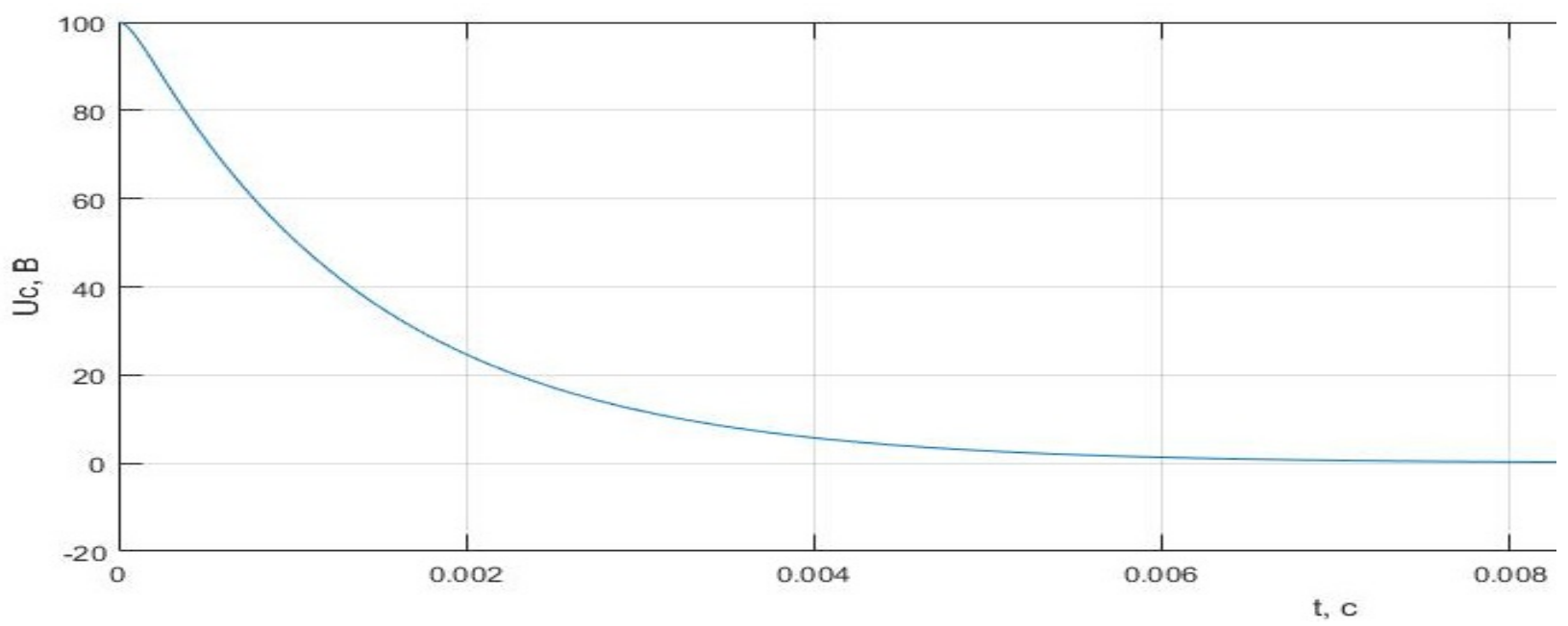

в)

Рис.2. Графіки зміни струмів $i_{1}(\mathrm{t})(a), i_{2}(\mathrm{t})$ (б) та напруги $\boldsymbol{U}_{C}(\mathrm{t})(\boldsymbol{s})$ при розрядженні смнісного накопичувача.

Fig.2 Charting of currents $i_{1}(\mathrm{t})(a), i_{2}(\mathrm{t})(\sigma)$ and voltage $U_{c}(\mathrm{t})(b)$ when discharging a capacitive drive. 
Отримані результати збігаються з експериментальною стендовою перевіркою, при цьому похибка склала в межах $3 . .5 \%$.

Висновки. Розроблена математична модель процесу розрядження ємнісного накопичувача на робочий орган електродинамічного привода насосу, що дозволила визначити вплив його параметрів на тривалість імпульсу розрядження . Для розрахунку індуктивності котушки виконавчого елементу привода запропоновано вираз, обчислення за яким дає задовільний результат. Розрахункові дані збігаються 3 результатами експериментальної стендової перевірки.

1. Васильев В.А. Анализ возможности применения емкостных накопителей энергии на электрическом подвижном составе. Современные технологии транспорту. Известия ПГУПС. 2011. № 1. С. 35-44.

2. Васько П.Ф. Питомі характеристики енергетичного потенціалу вітру на території України. Энергетика и электрификация. 1997. №4. С. 53-55.

3. Пустынников С.В. Исследование работы индуктивно-импульсного генератора. Современные наукоемкие технологии. 2015. № 3. С. 65-70.

4. Кулыгин В.И., Кирилюк И.О., Корогодский В.А., Ломов С.Г. Электродинамический привод. Патент а2006 05452 Опубл. 2009.02.27.

5. Зеленский А.В., Макарычев Ю.И. Радиокомпоненть дискретной и функциональной электроники. Куйбышев. 1986. 58 c.

6. Цейтлин Л.А. Индуктивности проводов и контуров. Л.-М. Госэнергоиздат. 1950. 230 с.

7. Калантаров П.Л., Цейтлин Л.А. Расчет индуктивностей: Справочная книга. Л. Энергоатомиздат. 1986. 488 с.

\section{REFERENCES}

1. Vasylyev V.A. Analiz mozhlyvosti vykorystannya yemnisnykh nakopychuvachiv enerhiyi na elektrychnomu rukhomomu skladi. [Analysis of the possibility of using capacitive energy storage devices on electric rolling stock]. Suchasni tekhnolohiyi transportu. Pratsi PHUPS. 2011. No. 1 Pp. 35-44.

2. Vasko. P.F. Osoblyvosti enerhetychnoho potentsialu enerhetyky na terytoriyi Ukrayiny. [Specific characteristics of wind energy potential in Ukraine]. Energy and Electrification. 1997 No. 4. Pp. 53-55.

3. Pustynnikov V.V. Doslidzhennya roboty induktyvnoimpulsnoho heneratora. [The study of the inductive-pulse generator. Modern high technology]. Modern high technologies. 2015. No. 3. Pp. 65-70.

4. Kulyhin V.I., Kyrylyuk I.O., Korohodskyy V.A., Lomov S.H. Elektrodynamichnyy pryvid. [Electrodynamic drive]. Patent a 2006 05452. Publ. 2009.02.27.

5. Zelenskyy A.V., Makarychev Yu.I. Radiokomponenty dyskretnoyi ta funktsionalnoyi elektroniky. [Radio components of discrete and functional electronics]. Kuybyshev. 1986. 58 p.
6. Tseytlin L.A. Induktyvnist provodiv i lantsyuhiv. [Inductance of wires and circuits]. L.M. Gosenergoizdat. 1950. 230 p.

7. Kalantarov P.L., Tseytlin L.A. Rozrakhunok induktyvnostey: Dovidnyk. [Inductance Calculation]. Reference Book. L. Enerhoatomizdat. 1986. 488 p.

\section{МАТЕМАТИЧЕСКАЯ МОДЕЛЬ ПРОЦЕССА РАЗРЯДА ЕМКОСТНОГО НАКОПИТЕЛЯ В АВТОНОМНОЙ ВЕТРОЭЛЕКТРОУСТАНОВКЕ С ЭЛЕКТРОДИНАМИЧЕСКИМ ПРИВОДОМ НАСОСА}

В.М. Головко, проф., докт. техн. наук,

В.П. Коханевич, канд.техн.наук, М.О. Шихайлов, А.М. Донец, канд.техн.наук, И.Ю. Перькова, инженер

Институт возобновляемой энергетики НАН Украины, 02094, г. Киев, ул. Гната Хоткевича, 20A

Неравномерность и случайность поступления энергии от возобновляемых источников энергии побуждает к разработке электроимпульсных установок для их использования. Одной из причин, сдерживаютих использование таких установок является отсутствие соответствующих математических моделей, не дает возможности осуществить оценку усилий, которые возникают при работе исполнительных элементов. В известных электродинамических приводах величина импульса силь обычно определяется как величина, пропорииональная диаметру катушки и равного ей по диаметру электропроводящего диска. Однако экспериментально установлено, что существует максимальная величина диаметров конструктивных элементов электродинамического привода, при превышении которо заметно снижается его эффективность. Такюе на эффективность электродинамического привода влияет толщина электрической катушки, поскольку КПД процесса передачи электрической энергии от конденсатора в электропроводящий диск электродинамического привода падает при большой толщине катушки. Кроме того, без понимания процесса разрядки в электроимпульсных установках часто невозможно осуществить выбор параметров зарядных устройств и емкостных накопителей. Желательно осуществлять такое согласование чтобы зарядки и разрядки были взаимонезависимы, что полагается на систему управления работой импульсного устройства. Чаще всего схема управления выключает разрядный блок зарядного во время прочесса розрядки.

Разработана математическая модель прочесса разрядки емкостного накопителя на рабочий орган электродинамического привода насоса, позволила определить влияние его параметров на длительность импульса разряда. Для расчета индуктивности катушки исполнительного элемента привода предложено выражение, вычисления по которому дает удовлетворительный результат. Расчетные данные совпадают с результатами экспериментальной стендовой проверки. Библ. 7, рис. 2.

Ключевые слова: ветроэлектроустановка, емкостной накопитель, имитационное моделирование, электродинамический привод, стохастических условиях изменения уровня скорости ветра 